\title{
Original article (short paper) \\ Relative age effect in FIFA U17 Emirates 2013 World Cup: analysis of players who effectively participated in the matches
}

\author{
Victor Amorim Andrade-Souza \\ Universidade Federal de Pernambuco, Vitória de Santo Antão, Brazil \\ Felipe Moniz \\ Israel Teoldo \\ Universidade Federal de Viçosa, Viçosa, Brazil
}

\begin{abstract}
The purpose of this study was to verify the date of birth is a decisive factor for the success of players selected by the coaches to participate in the FIFA U-17 World Cup Emirates 2013. The players' date of birth were classified into four quartiles of three months each (Q1 to Q4). In the qualifying round, 46.5\% of the selected players born in Q1, while $12.5 \%$ in Q4. This significantly different distribution occurred until the semi-finals. However, in the final match, there were no significant differences between Q1 and Q4. A similar relative age effect also occurred when analyzed only players who actually participated to the matches. Interestingly, despite there was birth date effect on performance in all World Cup stages except in the final, other issues should take into consideration for a team became champion.
\end{abstract}

Keywords: talent identification, youth competition, performance, birth-date

Resumo - "Efeito da idade relativa na Copa do Mundo FIFA Sub-17 Emirates 2013: análise de jogadores que efetivamente participaram nos Jogos." O objetivo deste estudo foi verificar se a data de nascimento é um fator decisivo para o sucesso de jogadores selecionados pelos treinadores para participar da Copa do Mundo Sub-17 Emirates 2013. As datas de nascimento dos jogadores foram classificadas em quatro quartis de três meses de cada (Q1 a Q4). Na qualificação, 46,5\% dos jogadores selecionados nasceram em Q1, enquanto $12,5 \%$ em Q4. Esta distribuição significativamente diferente ocorreu até às semifinais. Entretanto, na final, não houve diferenças significativas entre Q1 e Q4. Um efeito similar da idade relativa também ocorreu quando analisados apenas os jogadores que efetivamente participaram das partidas. Curiosamente, apesar de haver efeito da data de nascimento sobre o desempenho em toda Copa do Mundo, exceto na final, outras questões devem levadas em consideração para uma equipe sagrar-se campeã.

Palavras-chave: identificação do talento, competição de jovens, desempenho, data de nascimento

Resumen - "Efecto de la edad relativa en la Copa Mundial de fútbol sub-17 Emiratos 2013: Análisis de los jugadores que participaron efectivamente en los partidos." La finalidad de este estudio fue verificar la fecha de nacimiento es un factor decisivo para el éxito de los jugadores seleccionados por los entrenadores para participar de la Copa Mundial sub-17 FIFA Emirados Árabes Unidos 2013. Fecha de nacimiento se clasificaron en cuatro cuartiles de tres meses (Q1 a Q4). En la qualificación, 46,5\% de los seleccionados nacieron en Q1, mientras 12,5\% en Q4. Esta distribución diferente ocurrió hasta las semifinales. Sin embargo, en la final, no hubo diferencias entre Q1 y Q4. Un efecto similar también ocurrió cuando se analizaron sólo los jugadores que efectivamente hugaron. Curiosamente, mismo con efecto de la fecha de nacimiento en toda la Copa Mundial, excepto la final, otros temas deben tener en cuenta para un equipo hacerse campeón.

Palabras claves: identificación del talento, la competencia juvenil, rendimiento, fecha de nacimiento

\section{Introduction}

To promote age-related development and to ensure a fair competition with equal chance of success, soccer youth competitions organized by the Fédération Internationale de Football Association (FIFA) are categorized around 1-2 years period until Under-23 competitions, which each age group consists of players born between 1 January and 31 December (Helsen, Van Winckel, \& Williams, 2005; Jiménez \& Pain, 2008; Williams, 2010).
However, this system generates important differences in relative age: two children competing in the same category can be 11 or 23 months apart if they were born or not in the same year, respectively (Delorme, Boiché, \& Raspaud, 2010). Consequently, children who born early in the competitive year could be identified as "talented" in comparison with their counterparts who born later (Helsen et al., 2005).

Therefore, this overall difference in chronological age between individuals in the same category is defined as relative age effect and 
may result in significant differences in performance (Helsen et al., 2005). Recently, Williams (2010) examined the relative age effect in the Under-17 (U-17) FIFA World Cup competitions expecting that these physiological maturity differences could be minimized. However, he found a clear age effect with nearly $40 \%$ of the players were born in the first quarter of the year (January-March) while only $16 \%$ of the players were born in October, November, or December. Thereby, players who were born earlier in the year are more likely to be selected to play in a team. In addition, birth dates may increase the likelihood of players born in the first months of the year are identified as talented and therefore present greater tendency to be selected to participate in their national teams (Teoldo, Cardoso, \& Garganta, 2013).

Thus, the relative age effect may result in physical and cognitive (dis)advantages - i.e. significant variation in anthropometric variables (stature, body weight), physical development (strength, velocity), cognitive skills (tactical ability, game analysis), and psychological maturity, which promote differences in performance (Barnsley, Thompson, \& Barnsley, 1985; Helsen, Starkes, \& Van Winckel, 2000; Reilly et al., 2000; Teoldo et al., 2010).

Although a relative age effect is significantly evident in these previous studies, they analyzed the players who were selected to participate to the tournament, without considering if this effect really exists with the players who effectively participated to the matches. Additionally, Williams (2010) observed a relative age effect in the most successful teams (champions to fourth places) in all U-17 FIFA World Cups evaluated. However, no study observed if the relative age effect is determinant to advance to the next stages of the competition.

Therefore, the purpose of this study was to verify the date of birth is a decisive factor for the success of players selected by the coaches to participate in the FIFA U-17 World Cup Emirates 2013. It was hypothesized that the relative age effect would occur since the group stage until the final match and that it would be observed inclusively when analyzed only the players who effectively played.

\section{Methods}

\section{Participants}

A total of 503 players from 24 countries participated in this competition. The U-17 FIFA World Cup Emirates 2013 was analyzed. The players' dates of birth were classified into four groups of three months each, considering the cut-off date fixed from 1 January to 31 December. Therefore, the first quarter takes into account January, February and March (Q1), the second quarter includes April, May, June (Q2), the third quarter covers July, August, September (Q3), and the fourth quarter considers the months of October, November, and December (Q4).

\section{Procedures}

Rosters with player birthdates were obtained only from FIFA (http:// www.fifa.com). The birth month and year for each player was recorded and classified into four quarters. All 503 players were considered participants in group stages. As the stages of the tournament progressed, the players belonging to the countries that were eliminated were being excluded to analysis. For the round of 16, only players from 16 countries who participated in this phase $(n=$ 335 players) were analyzed. The inclusion criterion was repeated for subsequent stages of the tournament. Quarter-finals, eight countries ( $n=168$ players); semi-finals, four countries ( $n=84$ players); and final, the two countries finalists of the tournament ( $n=42$ players).

Following, the analysis for players who effectively played was held. Those players who effectively played more than one minute in each stage of the competition were included in the analysis ( $n=405$ players). Athletes who have not participated in any moment of the games were excluded ( $n=98$ players). In sequence, the same criteria for stages of the tournament were adopted. Round of 16 ( $n=223$ players), quarter-finals ( $n=108$ players), semi-finals ( $n=54$ players), final ( $n=26$ players).

\section{Data analysis}

Chi-square analyses were used to compare differences between expected birth-date distributions across the quarters of the selection year and it was also used to compare the distributions of each stage of the tournament. All statistical analyses were performed using the SPSS statistical software package (SPSS Inc., Chicago, IL, USA, 17.0). The level of significance was set at $p<.05$.

\section{Results}

Table 1 shows the birth-date distribution of the selected players by quartile for each phase of the U-17 World Cup 2013. In group stage, $46.5 \%$ of the selected players were born in Q1, while only $12.5 \%$ were born in Q4 $(p<.01)$. This distribution also occurred in round of 16 , quarter-finals and semi-finals (45.7\% and $13.1 \%$; $44.0 \%$ and $15.5 \%$; $41.7 \%$ and $14.3 \%$; Q1 and Q4, respectively; $p<.01)$. However, in the final match, there were no significant differences between Q1 and Q4 (28.6\% and $23.8 \%$, respectively; $p=.79$ ). Additionally, Q1 was also significantly higher than Q2 and Q3 in all phase of the World Cup, except in the final match $(p<.01)$. Moreover, Q2 was significantly higher than Q3 and Q4 in the group stage (Q2: 25.1\%, Q3: 15.9\%, and Q4: $12.5 \% ; p<.05)$. In round of 16 , Q2 were also significantly higher than Q4 $(26.9 \%$ and $13.1 \%$, respectively; $p<.05)$.

Table 1. Number of players selected by coaches who born in each of the four quarters of the year according to each tournament phase $(n ; \%)$.

\begin{tabular}{ccccccc}
\hline World Cup phase & Q1 & Q2 & Q3 & Q4 & $X^{2}$ & p \\
\hline Qualifying round & $234(46.5 \%)$ & $126^{\mathrm{a}}(25.1 \%)$ & $80^{\mathrm{a}, \mathrm{b}}(15.9 \%)$ & $63^{\mathrm{a}, \mathrm{b}}(12.5 \%)$ & 141.1 & $<.01$ \\
Round of 16 & $153(45.7 \%)$ & $80^{\mathrm{a}}(26.9 \%)$ & $58^{\mathrm{a}}(17.3 \%)$ & $44^{\mathrm{a}, \mathrm{b}}(13.1 \%)$ & 84.2 & $<.01$ \\
Quarter-finals & $74(44.0 \%)$ & $40^{\mathrm{a}}(23.8 \%)$ & $28^{\mathrm{a}}(16.7 \%)$ & $26^{\mathrm{a}}(15.5 \%)$ & 35.2 & $<.01$ \\
Semi-finals & $35(41.7 \%)$ & $19^{\mathrm{a}}(22.6 \%)$ & $18^{\mathrm{a}}(21.4 \%)$ & $12^{\mathrm{a}}(14.3 \%)$ & 13.8 & $<.01$ \\
Final & $12(28.6 \%)$ & $8(19.0 \%)$ & $12(28.6 \%)$ & $10(23.8 \%)$ & 1.0 & $=.79$
\end{tabular}

Q1: first quarter; Q2: second quarter; Q3: third quarter; Q4: fourth quarter; $X^{2}$ : chi-square values; ${ }^{\text {a }}$ : significantly different from Q1 $(p<.05)$; ${ }^{\text {}}$ : significantly different from Q2 $(p<.05)$. 
Table 2 represents the birth-date distribution by quartile for the players who effectively play in each phase of the U-17 World Cup. Overall, 46.9\% of the effectively players were born in Q1, while only $12.6 \%$ in Q4 $\left(X^{2}=117.1 ; p<.01\right)$. This distribution also occurred in round of 16, quarter-finals and semi-finals $(47.6 \%$ and $12.1 \% ; 44.5 \%$ and $14.8 \% ; 46.3 \%$ and $16.7 \%$; Q1 and Q4, respectively; $p<.01)$. Similarly, in the final match, the birth date distribution of effective was unfavorable, with $30.8 \%$ for both Q1 and Q4 $(p=.45)$. Interestingly, the U-17 World Cup champion was Nigeria which showed an inverse birth month distribution with $26.1 \%$ of the players born in Q4 while only 4.4\% in Q1. Additionally, Q1 was also significantly higher than Q2 and Q3 in all phase of the World Cup, except in the final match $(p<.01)$. Moreover, Q2 was significantly higher than Q3 and Q4 in the group stage (Q2: 24.9\%, Q3: $15.6 \%$, and Q4: $12.6 \% ; p<.05)$. In round of 16 , Q2 were also significantly higher than Q4 (23.3\% and 12.1\%, respectively; $p<.05)$.

Table 2. Number of players born who effectively play according to each tournament phase $(n ; \%)$.

\begin{tabular}{|c|c|c|c|c|c|c|}
\hline World Cup phase & Q1 & Q2 & Q3 & $\mathrm{Q4}$ & $X^{2}$ & $\mathbf{p}$ \\
\hline Qualifying round & $190(46.9 \%)$ & $101^{\mathrm{a}}(24.9 \%)$ & $63^{\mathrm{a}, \mathrm{b}}(15.6 \%)$ & $51^{\mathrm{a}, \mathrm{b}}(12.6 \%)$ & 117.1 & $<.01$ \\
\hline Round of 16 & $106(47.6 \%)$ & $52^{\mathrm{a}}(23.3 \%)$ & $38^{\mathrm{a}}(17.0 \%)$ & $27^{\mathrm{a}, \mathrm{b}}(12.1 \%)$ & 66.0 & $<.01$ \\
\hline Quarter-finals & $48(44.5 \%)$ & $24^{\mathrm{a}}(22.2 \%)$ & $20^{\mathrm{a}}(18.5 \%)$ & $16^{\mathrm{a}}(14.8 \%)$ & 22.9 & $<.01$ \\
\hline Semi-finals & $25(46.3 \%)$ & $12^{\mathrm{a}}(22.2 \%)$ & $8^{a}(14.8 \%)$ & $9^{a}(16.7 \%)$ & 13.7 & $<.01$ \\
\hline Final & $8(30.8 \%)$ & $3(11.5 \%)$ & $7(26.9 \%)$ & $8(30.8 \%)$ & 2.6 & $=.45$ \\
\hline
\end{tabular}

Q1: first quarter; Q2: second quarter; Q3: third quarter; Q4: fourth quarter; $X^{2}$ : chi-square values; ${ }^{\text {a }}$ : significantly different from Q1 (p $<0.05$ ); ${ }^{\mathrm{b}}$ : significantly different from Q2 $(p<.05)$.

\section{Discussion}

The purpose of the present study was to verify the date of birth is a decisive factor for the success of players selected by the coaches to participate in the FIFA U-17 World Cup Emirates 2013. The main finding of this study was that the relative age effect occurred in all stages of the tournament to both selected and effective players, excepted in the final match.

Since the most of the players who were selected by the coaches and who effectively play in this U-17 competition were born between January and March. Although it could be expected a reduction in these physiological maturity differences between players, these findings corroborate the results by Williams (2010) which demonstrated that nearly $40 \%$ of the players were born in Q1 while only $16 \%$ were born in Q4. Thus, it demonstrates that the quartiles of birth influence directly the selection of players for this level of competition. In practice, national teams' coaches prefer select players born in the first quartile of the year to compete in international competitions due to the complexity and the high level of these competitions.

In a study conducted by Helsen, Starkes, and Van Winckel (1998) showed that youth players who were born earlier are identified as "talented" and exposed to higher levels of practice, which facilitate the further involvement in professional soccer. Three arguments explain this relative age effect: the talent identification/selection are influenced by physical attributes rather than sport skill; the competitions organized in a 24-month category; and excessive stress caused by the early age that begins high levels of soccer competitions.

This process of identification/selection of the players within the same category allows age bias and as a result, a potential talent can be wasted in this process. Probably, less mature players drop out or fail to receive advanced training during this process, while older players fail to develop the technical aspects for their game. Therefore, coaches should encourage players on their maximum potential and training should focus on developing the skills independent of their maturity status (Jiménez \& Pain, 2008; Williams, 2010).

Interestingly, countries that were advancing in the U-17 World Cup also have most of players born in Q1. For example, in round of 16 stage $45.7 \%$ of the selected players were born in Q1 (47.5\% for effective players) while 13.1\% were born in Q4 (12.1\% for effective players). This relative age effect was observed up to the semi-final stage. Although we are the first to observe this age effect in each stage of the tournament, it is likely that this distribution has occurred in other competitions of this highest level.

In this regard, a significant variation in physical, cognitive and psychological maturity may aid the teams to progress in the competition (Helsen et al., 2000; Reilly et al., 2000). The consequences of the relative age effect are clearly present in competitions involving youth national teams.

On the other hand, the U-17 World Cup 2013 champion showed an inverse birth month distribution with most of the players born in Q4. For example, in the final match $30.8 \%$ of the players who played from Nigeria were born in Q4. Probably, this unexpected behavior occurs with Nigeria because the tactical aspects may be overlapped to the physical components. The tactical aspects were unaffected by relative age effects because in this level, players are benefited from training and competing processes with better teammates and against better opponents, which promote an equal development (Teoldo et al., 2010). Therefore, the relative age effect is not necessarily a guarantee of success.

Africa region showed a reverse age effect (Williams, 2010). For these nations, players were more likely to have been born in Q4 with nearly 14\% born in December. The author unknown the reason for this phenomenon, but they suspected that physical stature may play a major role since the African players born in 
the later part of the year tend to be taller than those born earlier. Moreover, he also suspected that such a large percentage of players born in a single month there may be errors in the reporting of actual birth dates.

\section{Conclusion}

In summary, the purpose of the present study confirm a relative age effect occurred in all stages of the U-17 World Cup Emirates 2013 to both selected and effective players, excepted in the final match. Interestingly, although the birth date effect can lead to advantages for players who born in the first months of the year compared with the others of the same category, other issues should take into consideration for a team became champion.

\section{References}

Barnsley, R., Thompson, H. \& Barnsley, P. (1985). Hockey success and birth date: the relative age effect. Canadian Association for Health, Physical Education and Recreation Journal, 51, 23-28.

Delorme, N., Boiché, J., \& Raspaud, M. (2010). Relative age effect in elite sports: Methodological bias or real discrimination? European Journal of Sport Science, 10(2), 91-96. doi: 10.1080/17461390903271584.

Helsen, W., Starkes, J., \& Van Winckel, J. (1998). The influence of relative age on success and dropout in male soccer players. American Journal of Human Biology, 10, 791-798.

Helsen, W., Starkes, J., \& Van Winckel, J. (2000). Effect of a change in selection year on success in male soccer players. American Journal of Human Biology, 12, 729-735.

Helsen, W., Van Winckel, J., \& Williams, A. (2005). The relative age effect in youth soccer across Europe, Journal of Sports Sciences, 23, 629-636. doi:10.1080/02640410400021310.

Jiménez, I., \& Pain, M. (2008). Relative age effect in Spanish association football: Its extent and implications for wasted potential. Journal of Sports Sciences, 26, 995-1003. doi:10.1080/02640410801910285.

Reilly, A., Williams, A., Nevill, A., \& Franks, A. (2000). A multidisciplinary approach to talent identification in soccer. Journal of Sports Sciences, 18, 695-702.

Teoldo, I., Garganta, J., Greco, P., Mesquita, I., \& Seabra, A. (2010). Influence of relative age effects and quality of tactical behaviour in the performance of youth soccer players, International Journal of Performance Analysis of Sport, 10, 82-97.
Teoldo, I., Cardoso, F., \& Garganta, J. (2013). Could the Human Development Index and Birth-Date of the players influence the climbing up to higher performance in Soccer?, Motriz, 19, 34-45.

Williams, J. (2010). Relative age effect in youth soccer: analysis of the FIFA U17 World Cup competition. Scandinavian Journal of Medicine and Science in Sports, 20, 502-508. doi: 10.1111/j.1600-0838.2009.00961.x.

\section{Authors' note}

Victor Andrade-Souza (victor.andradesouza@ufpe.br) is affiliated with the Sport Sciences Research Group, Department of Physical Education and Sports Science (CAV), Federal University of Pernambuco, Vitória de Santo Antão, Pernambuco, Brazil.

Felipe Moniz (fmcarvalho1@gmail.com) and Israel Teoldo (israelteoldocosta@gmail.com) are affiliated with the Centre of Research and Studies in Soccer, Departamento de Educação Física, Universidade Federal de Viçosa, Viçosa, Brasil.

\section{Corresponding author}

Victor Amorim Andrade-Souza

Sport Sciences Research Group, Department of Physical Education and Sports Science (CAV), Federal University of Pernambuco, Brazil. Alto do Reservatório Street, Bela Vista, Vitória de Santo Antão 55608680, PE, Brazil.

Phone: +55-81-99999-6304.

E-mail: victor.andradesouza@ufpe.br

Manuscript received on May 6, 2015

Manuscript accepted on October 11, 2015

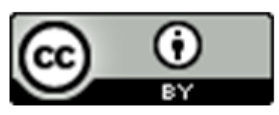

Motriz. The Journal of Physical Education. UNESP. Rio Claro, SP, Brazil - eISSN: 1980-6574 - under a license Creative Commons - Version 3.0 